\title{
The Effectiveness of STEM-Based Student Worksheets to Improve Students' Data Literacy
}

\author{
Ratih Galuh Rahmawati ${ }^{1, *}$ Insih Wilujeng ${ }^{2}$, and Arina Umu Kamila ${ }^{1}$ \\ ${ }^{1}$ Master of Physics Education, Faculty of Mathematics and Natural Sciences, Universitas Negeri Yogyakarta, \\ Indonesia \\ ${ }^{2}$ Department of Natural Sciences Education, Faculty of Mathematics and Natural Sciences, Universitas Negeri \\ Yogyakarta, Indonesia \\ *Corresponding author. Email: ratihgaluh.2019@student.uny.ac.id
}

\begin{abstract}
The objective of this research was to find out the effectiveness of STEM-based student worksheets to improve data literacy. The research method used is in the form of Quasi-experimental research design with the OneGroup Pretest-Posttest. Students of class XI MIPA 2 in MAN 2 Yogyakarta were the subjects of this research. The data analysis included the results of the pretest, posttest, N-Gain test and non-parametric statistical tests to determine the increase in student data literacy descriptively. Based on the findings of the data analysis, it was achieved: 1) there was an increase in the value of data literacy taught using STEM-based student worksheets with N-Gain of $71 \%$ in the high category; and 2) STEM-based student worksheets are effective for improving participant data literacy by obtaining sig values. equal to 0.000 which is smaller than $\alpha=0.005$
\end{abstract}

Keywords: STEM, Student worksheets, Data literacy

\section{INTRODUCTION}

The developments that occur in the 21 st century have a fundamental effect on various aspects of life in the fields of economy, transportation, technology, information, and communication. In response to this, education plays an important role in producing quality human resources with a series of competencies needed in this century [1]. Several things are strengthened from the 2013 revised 2017 Curriculum listed in Permendikbud Number 23 of 2017 concerning School Days, one of which is literacy mastery. Mastery of literacy is a competency that is useful for students to become qualified human resources and able to face global competition. Therefore, the government is promoting new literacy, one of which is data literacy. The need for data-based skills continues to increase in various aspects of life [2]. Data-based decision making (big data) has become the top position by shifting negotiation skills and intelligence in thinking and acting [3]. The ability to read, analyze, and make conclusions about the data or information collected is connected to data literacy [2]. Other competencies such as mathematical literacy, critical thinking skills, analytical skills, argumentative abilities, and others can also be born from data literacy [4]. A person with low data literacy skills will find it difficult to find a career position in the current 21 st century era. This is because almost all jobs in various fields are related to data. For example, in the field of sociology, it focuses on data collection and statistical analysis skills, economics emphasizes data analysis and modeling capabilities, and bioinformatics is related to the ability to use computers as a tool to store, retrieve, and analyze biological information [5]

Data literacy is one of the abilities that must be emphasized in learning, especially physics. Physics is categorized as physical knowledge which includes processes, products, and scientific attitudes that are cyclic, interrelated and explain how these natural phenomena are through observation and research. Data literacy in learning physics therefore plays a role in encouraging thought skills that are helpful in solving problems in daily life [4]. Besides, data literacy is needed because the data contains a variety of information that is completely compiled so that it requires appropriate observation skills for students to obtain information [6]. Data literacy in education aims to make students become data literate science 
workers and develop professional students in data management [7].

Research by the SDL (Science Data Literacy) project on student data literacy shows that the level of data management literacy is still poor. As the average percentage of the overall data literacy ability is $55.72 \%$ [4]. Several factors influence the achievement of data literacy competencies, among which learning is still dominated by the role of the teacher and the lack of innovation in the application of the learning approach and learning tools used [4]. Reflecting on this problem, activities, approaches, and learning tools are needed that can develop students' data literacy [8].

Learning activities through practicum activities can make the physics learning process interesting and easy to understand [9]. One of the learning media that can support this activity is student worksheets. Student worksheets are considered to be able to increase students' data literacy because it involves providing information and communicating their findings to others. This is in line with learning activities at student worksheets which require students to communicate the results of student work experiments by following scientific work principles [10]. Practical activities in student worksheets train the involvement of students in active learning [11] so that the participation of students in learning will increase.

However, the use of student worksheets has only emphasized the cognitive aspects without paying attention to aspects of reasoning and evaluation and their application to scientific concepts [12]. Besides, the combined model in student worksheets only leads to unsustainable experimental stages so that students' understanding is limited to experiments [13]. Therefore, efforts are needed to develop data literacy skills and sustainable understanding that are realized through the right learning approach. One of them is through the STEM (Science, Technology, Engineering, and Mathematics) approach.

The STEM approach integrates learning with four disciplines, including science, technology, engineering, and mathematics, into one learning process [14] that can maximize the quality of students' knowledge and skills [15]. The STEM approach emphasizes several aspects of the learning process, namely: 1) asking questions and defining problems; 2) creating and using models; 3) planning and conducting investigations; 4) analyzing and interpreting data; 5) using mathematics, information technology, and computers and thinking computationally; 6) generating explanations (science) and designing solutions (engineering); 7) engage in evidence-based arguments; 8) knowledge is obtained, evaluated and confirmed [16]. The STEM approach is considered suitable for improving the data literacy of students based on these aspects. STEM learning can also develop skills in the development and use of different data forms [17].

STEM research is mostly to improve learning outcomes, attitudes towards science learning, learning motivation, creativity, and learning activities, while STEM research to improve data literacy is still rarely done. STEM can improve students' perceptions and attitudes during the learning process [18]. Besides, the STEM approach can increase the creativity of students in solving problems in everyday life [18] and can increase the learning motivation of students [19], [20]. Based on this, it can be concluded that there are many positive effects obtained by the process through the use of the STEM approach in learning. The combination of student worksheets and STEM is an appropriate learning medium to increase student data literacy. Therefore, this study was conducted to answer the problem of how the effectiveness of STEM-based student worksheets to improve students' data literacy.

\section{RESEARCH METHODS}

\subsection{Research design and research subjects}

This research was a descriptive quantitative research with Quasi Experiment research type. Quasi Experiment is research whose structure is identical to that of an experiment, but since the analysis is limited to random assignments, the circumstances and experiences of the participants lack control [21]. The research design used was One-Group Pretest-Posttest where the ability of a group was tested and observed before and after treatment, as shown in the following figure [22].

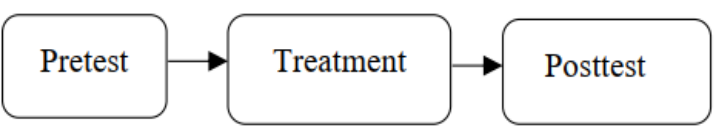

Figure 1 One-group pretest-posttest

The design of the One-Group Pretest-Posttest was chosen because it can compare the outcomes before and after being treated using the same measuring instrument with the same participants [22].

The research was conducted at MAN 2 Yogyakarta with the research subjects of class XI MIPA students. The research was conducted in the 
MIPA 2 class as a welding experiment for as many as 22 students. The determination of the subject based on the purposive sampling technique. Learning in the experimental class uses STEM-based student worksheets on the light waves' topic.

\subsection{Research procedure}

This research procedure is in the form of formulating problems, determining research objectives, selecting research titles, studying literature, making research instruments, validating instruments, collecting data, analyzing data, drawing conclusions, and compiling reports. Making research instruments includes making lesson plans, STEMbased student worksheets, and data literacy assessment instruments. The research data was obtained through a test question instrument aimed at class XI MIPA 2 students. The data literacy test instrument used four indicators consisting of six questions. Four indicators include collecting data [5], understanding data [23], analyzing data [24] and managing data [25].

\subsection{Data analysis}

Testing the effectiveness using a qualitative descriptive approach and quantitative statistical analysis. Quantitative statistical analysis was performed using the N-Gain test and non-parametric statistical tests. The N-Gain test to determine the increase in the pretest-posttest value using the equation:

$N-$ gain $=\frac{S_{\text {post }}-S_{\text {pre }}}{S_{\max }-S_{\text {pre }}}$

with the $\mathrm{N}$-gain acquisition category [26]:

Table 1. N-gain acquisition category

\begin{tabular}{|l|l|l|}
\hline No. & Interval & Category \\
\hline 1 & $(\mathrm{~g}) \geq 0,70$ & High \\
\hline 2 & $0,30 \leq(\mathrm{g}) \leq 70$ & Medium \\
\hline 3 & $(\mathrm{~g})<30$ & Low \\
\hline
\end{tabular}

In addition, a statistical test was performed with the aid of the SPSS 21.0 software to assess the increase between the pretest and posttest by conducting a non-parametric statistical test using the Wilcoxon test. The basis for decision making is if the sig. $>0.05$ then $\mathrm{H}_{0}$ is accepted but if the value is sig. $>0.05$ then $\mathrm{H}_{0}$ is rejected.

\section{RESULT AND DISCUSSION}

Testing the effectiveness of STEM-based student worksheets was carried out in one experimental class using STEM-based student worksheets with light waves topic. This effectiveness test is to determine the increase in pretest and posttest scores and to determine the increase in students' data literacy skills.

\subsection{Description of Student's Pretest-posttest Data Literacy Value}

Table 2. Description of the pretest-posttest data literacy values of students.

\begin{tabular}{|l|l|l|}
\hline & Pretest & Posttest \\
\hline Sample (N) & 22 & 22 \\
\hline Minimum score & 33 & 50 \\
\hline Maximum score & 83 & 100 \\
\hline Mean & 46.82 & 83.23 \\
\hline Std. Deviation & 18.461 & 13.533 \\
\hline
\end{tabular}

Based on Table 2, it shows that there is a relatively high difference in the concentration of the pretest and posttest data literacy scores of students. The average value of the pre-test and post-test respectively were 46.82 and 83.23 . This shows that the posttest score is higher than the pretest score, it can be concluded that there is an increase in the value of data literacy taught using STEM-based student worksheets.

\subsection{Improve Student Data Literacy}

There is an improvement in the data literacy of students that can be seen with the $\mathrm{N}$-Gain acquisition category, namely low, medium, and high categories, through the measurement of normalization (N-Gain). The results of the $\mathrm{N}$-Gain score calculation can be seen in Table 3 below:

Table 3. Description of N-Gain data literacy learners

\begin{tabular}{|l|l|}
\hline Analysis & Percentage N- Gain Score (\%) \\
\hline Average & 71 \\
\hline Lowest & 25,37 \\
\hline Highest & 100 \\
\hline Variance & 495.54 \\
\hline St. Deviation & 22.26 \\
\hline
\end{tabular}

Based on the results of the $\mathrm{N}-$ Gain analysis in Table 3, it is known that the average N-Gain obtained is $71 \%$ in the high category. Furthermore, the 
percentage of students' N-Gain score achievement can be seen in Figure 2.

Figure 2 indicates that $59 \%$ of students have improved high-category data literacy; $36.36 \%$ of students observed an improvement in moderate category in data literacy; and $4.54 \%$ of students experienced an increase in low-category data literacy. A significant percentage, namely $59 \%$ for the class, was obtained by $\mathrm{N}$-Gain with high category. This suggests that, after receiving treatment using STEMbased student worksheets, there is an improvement in the data literacy abilities of students.

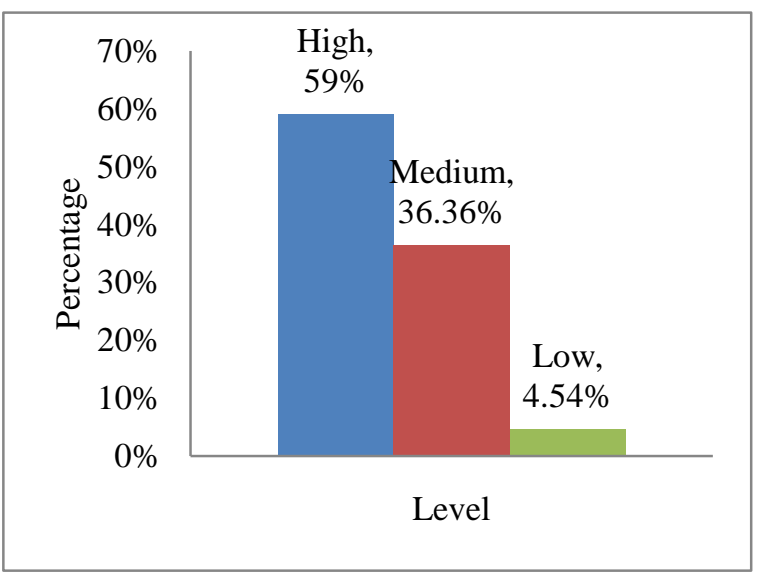

Figure 2 The percentage of students' data literacy NGain scores

\subsection{Effectiveness of STEM-based Student Worksheets on Student Data Literacy}

The effectiveness test was conducted using the Wilcoxon hypothesis test to assess the difference between students' pre-test and post-test outcomes of students on the use of STEM-based student worksheets.

Table 4. Wilcoxon test results

\begin{tabular}{|l|l|}
\hline & Post Test-Pre Test \\
\hline$Z$ & $-4,136 \mathrm{~b}$ \\
\hline Asymp. Sig. (2-tailed) & .000 \\
\hline
\end{tabular}

The significance value is $0.000<0.005$, based on the results of hypothesis testing using Wilcoxon in Table 4 , so $\mathrm{H}_{0}$ is rejected and $\mathrm{H}_{\mathrm{a}}$ is accepted. This suggests that in the pre-test and post-test outcomes, there are differences in the data literacy abilities of students. So, it can be concluded that the STEMbased student worksheets are effective for improving the data literacy of MAN 2 Yogyakarta students.

\subsection{Discussion}

Learning using STEM-based student worksheets has a positive effect on students, especially in terms of increasing data literacy. The increase in students 'data literacy using STEM-based student worksheets was determined from the achievement of the N-Gain score through the students' pretest and posttest results. The $\mathrm{N}$-Gain score obtained indicates the high category. The effectiveness of increasing data literacy skills after using STEM-based student worksheets is effective, where based on the Wilcoxon test results obtained a sig $<0.05$, which indicates that $\mathrm{H}_{0}$ is rejected. This is in line with many studies that, after using the STEM approach, show an improvement in data literacy skills [17], [27].

The STEM approach in student worksheets is in the form of teaching, learning content, and scientific practice which includes science and mathematics by integrating relevant engineering practices and engineering design technologies [28]. The treatment given in this study was that students were trained to improve data literacy indicators, including finding data, understanding data, analyzing data, and processing data through learning using STEM-based student worksheets. The indicators can be fulfilled because students carry out learning in accordance with the activities at the student worksheets. This activity includes interpreting the phenomenon of light waves in everyday life, solving problems, designing experiments, analyzing and answering questions from detailed and systematic experimental steps in accordance with student worksheets. Students look active and enthusiastic in all activities, especially in interpreting phenomena and designing experiments. This shows that STEM-based student worksheets help students connect the principles of physics with everyday life so that they can improve student learning outcomes.

STEM aspects of learning in the form of asking science questions and defining problems, planning and investigating, using mathematics; technology and computers; and computational thinking, and obtaining, evaluating and communicating information [29]. From these aspects, it helps develop students' data literacy skills, where data is obtained, interpreted, analyzed and developed in learning. The development of data literacy competencies in students can provide benefits for the alignment of skills needed for the future [30]. The STEM approach is the most appropriate form of approach in preparing the literacy generation to answer the demands of the 21 st century [31]. There are several efforts that can be made to improve 21 st century skills, especially 
student data literacy, including educators who can innovate in using student-centered learning models. Learning models that can be used are for example Project Based Learning, Inquiry, Problem Based Learning and Discovery Learning which are recommended as STEM-based learning models [27].

\section{CONCLUSION}

Students' data literacy ability has improved, with post-test results higher than the students' pre-test results in MAN 2 Yogyakarta. In the high category, the average $\mathrm{N}$-Gain obtained was. In addition, STEM-based student worksheets have proven effective in improving the data literacy of students, especially in class XI MIPA MAN 2 Yogyakarta light waves topic. Based on this, educators are expected to be able to design learning tools related to the abilities needed in the 21 st century, including learning with the STEM approach.

\section{REFERENCES}

[1] Y. Liao, E.F.R. Loures, F. Deschamps, G. Brezinski, A. Venâncio, The Impact of The Fourth Industrial Revolution: A CrossCountry/Region Comparison, Production 28 (2018). DOI: https://doi.org/10.1590/0103$\underline{6513.20180061}$

[2] T. Koltay, Data literacy: in search of a name and identitiy, Journal of Documentation 71(2) (2015) 401-415. DOI: https://doi.org/10.1108/JD-02-2014-0026

[3] D. Lase, Pendidikan di Era Revolusi Industri 4.0, Jurnal Sundermann 1(1) (2019) 28-43. DOI: https://doi.org/10.36588/sundermann.v1i1.18

[4] A. Ambarwati, Sarwanto, Sukarmin, The profile of students' data literacy at SMA Negeri 1 Karanganyar, in: Journal of Physics: Conference Series, vol. 1511, IOP Publishing, Bristol, 2020 pp. 1-10. DOI: https://doi.org/10.1088/17426596/1511/1/012028

[5] Z. Qi, Research on scientific data literacy education system, Open Journal of Social Sciences 6(6) (2018) 187-199. DOI: https://doi.org/10.4236/jss.2018.66017

[6] C.A. Dewi, Y. Khery, M. Erna, An Ethnoscience Study in Chemistry Learning to Develop Scientific Literacy, Jurnal Pendidikan IPA Indonesia 8(2) (2019) 279-287. DOI: https://doi.org/10.15294/jpii.v8i2.19261
[7] R. Schneider, Research data literacy, in: Proceedings of The First European Conference on Information Literacy, Springer, Berlin, 2013, pp 134-140. DOI: https://doi.org/10.1007/9783-319-03919-0_16

[8] W. Y. Lestari, D. Rosana, Analysis of Junior High School students' data literacy in Ciamis with local potential kampung adat Kuta, in: Journal of Physics: Conference Series, vol. 1440, IOP Publishing, Bristol, 2020, pp. 1-7. DOI: $\quad$ https://doi.org/10.1088/1742$\underline{6596 / 1440 / 1 / 012097}$

[9] N. Pratiwi, Yulkifli, Peningkatan Kompetensi Keterampilan Peserta Didik Berbantuan LKPD Berbasis Model Discovery Learning Pada Materi Fluida, Indonesian Journal of Science and Mathematics Education 2(1) (2019) 130139.

DOI: https://doi.org/10.24042/ijsme.v2i1.4219

[10] P. Siahaan, P. Dewi, E. Suhendi, Introduction, Connection, Application, and Extension (ICARE) Learning Model: The Impact on Students' Collaboration and Communication Skills, Jurnal Ilmiah Pendidikan Fisika AlBiRuNi 9(1) (2020) 109-119. DOI: https://doi.org/10.24042/jipfalbiruni.v9i1.5547

[11] W. Fitriani, F. Bakri, Sunaryo, Pengembangan Lembar Kerja Siswa (LKS) Fisika untuk Melatih Kemampuan Berpikir Tingkat Tinggi (High Order Thinking Skill), Jurnal Wahana Pendidikan Fisika 2(1) (2017) 36-42. DOI: https://doi.org/10.17509/wapfi.v2i1.4901

[12] T. Rahayu, S. Syafril, W. Wati, Y. Yuberti, The Application of STAD-Cooperative Learning in Developing Integrated Science on Students Worksheet, Jurnal Ilmiah Pendidikan Fisika AlBiRuNi 6(2) (2017) 247-254. DOI: https://doi.org/10.24042/jipfalbiruni.v6i2.1933

[13] S. Ramayanti, S. Utari, D. Saepuzaman, Training students' science process skills through didactic design on work and energy, in: Journal of Physics: Conference Series, vol. 895, IOP Publishing, Bristol, 2017 pp. 1-8. DOI: https://doi.org/10.1088/1742$\underline{6596 / 895 / 1 / 012110}$

[14] N. Khoiriyah, Abdurrahman, I. Wahyudi, Implementasi Pendekatan Pembelajaran STEM untuk Meningkatkan Kemampuan Berpikir Kritis Siswa pada Materi Gelombang Bunyi, Jurnal Riset dan Kajian Pendidikan Fisika 5(2) 
(2018) 53-62. DOI: http://dx.doi.org/10.12928/jrkpf.v5i2.9977

[15] S. Ercan, E.B. Altan, B. Tastan, I. Dag, Integrating GIS into Science Classes to Handle STEM Education, Journal of Turkish Science Education 13 (2016) 30-43. DOI: http://doi.org/10.12973/tused.10169a

[16] A. Muyassarah, T. Ratu, M. Efran, Pengaruh Pembelajaran Fisika Berbasis STEM Terhadap Kemampuan Motorik Siswa, in: Prosiding Seminar Nasional Fisika dan Aplikasinya, Universitas Sebelas Maret, Surakarta, 2019, pp $1-6$. DOI: https://doi.org/10.20961/prosidingsnfa.v4i0.359 $\underline{06}$

[17] J. Cook, D. Bedford, S. Mandia, Raising Climate Literacy Through Addressing Misinformation: Case Studies in AgnotologyBased Learning, Journal of Geoscience Education 62(3) (2013) 296-306. DOI: https://doi.org/10.5408/13-071.1

[18] F. Gülhan, F. Şahin, The Effects of ScienceTechnology-Engineering-Math (STEM) Integration on 5th Grade Students' Perceptions and Attitudes Towards These Areas, International Journal of Human Science 13(1) (2016) 601-620. DOI: http://doi.org/10.14687/ijhs.v13i1.3447

[19] J.R. Chittum, B.D. Jones, S. Akalin, A.B. Schram, The Effects of An Afterschool STEM Program on Students' Motivation and Engagement, International Journal of STEM Education 4(1) (2017) 1-16. DOI: https://doi.org/10.1186/s40594-017-0065-4

[20] J. Vennix, P. den Brok, R. Taconis, Do Outreach Activities in Secondary STEM Education Motivate Students and Improve Their Attitudes towards STEM?, International Journal of Science Education 40(11) (2018) 1263-1283. DOI:

https://doi.org/10.1080/09500693.2018.1473659

[21] G. J. Privitera, L. A. Delzell, Reasearch methods for education, SAGE Publications, 2018.

[22] J. R. Fraenkel, N. E. Wallen, H. H. Hyun, How to Design and Evaluate Research in Education, 8th ed. Mc Graw Hill, 2012.

[23] J. Carlson, L. Johnston, B. Westra, M. Nicholas, Developing An Approach for Data Management
Education: A Report From The Data Information Literacy Project, The International Journal of Digital Curation 8(1) (2013) 204-217. DOI: https://doi.org/10.2218/ijdc.v8i1.254

[24] C. Dichev, D. Dicheva, Towards Data Science Literacy, in: Procedia Computer Science, vol. 108, Elseiver, Amsterdam, 2017, pp 2151-2160. DOI:

https://doi.org/10.1016/j.procs.2017.05.240

[25] T. Koltay, Data Governance, Data Literacy and The Management of Data Quality, International Federation of Library Associations and Institutions 42(4) (2016) 303-312. DOI: https://doi.org/10.1177/0340035216672238

[26] D.E. Meltzer, The Relationship Between Mathematics Preparation and Conceptual Learning Gains in Physic: A Possible "Hidden Variable" in Diagnostic Pre-Test Score, American Journal of Physics 70(12) (2002) 1259-1268.

DOI: https://doi.org/10.1119/1.1514215

[27] L. Rahmawati, I. Wilujeng, Sutrisna, Application of STEM learning approach through simple technology to increase data literacy, in: Journal of Physics: Conference Series, vol. 1440, IOP Publishing, Bristol, 2020 pp. 1-9. DOI: http://doi.org/10.1088/1742$\underline{6596 / 1440 / 1 / 012047}$

[28] S. Ardianti, D. Sulisworo, Y. Pramudya, Efektivitas blended learning berbasis pendekatan STEM education berbantuan schoology untuk meningkatkan critical thinking skill pada materi fluida dinamik, in: Prosiding Seminar Nasional Pendidikan KALUNI, vol. 2, Universitas Indraprasta, Jakarta, 2019, pp 240246.

DOI: http://dx.doi.org/10.30998/prokaluni.v2i0.67

[29] J. Afriana, A. Permanasari, A. Fitriani, Penerapan Project-Based Learning Terintegrasi STEM untuk Meningkatkan Literasi Sains Siswa Ditinjau dari Gender, Jurnal Inovasi Pendidikan IPA 2(2) (2016) 202-212. DOI: https://doi.org/10.21831/jipi.v2i2.8561

[30] D. MacMillan, Developing Data Literacy Competencies to Enhance Faculty Collaborations, Liber Quarterly 24(3) (2015) 140-160. DOI: http://doi.org/10.18352/lq.9868

[31] AA. Zamista, Increasing persistence of college students in Science Technology Engineering and Mathematic (STEM), Curricula: Journal of Teaching and Learning 3(1) (2018) 22-31. DOI: http://dx.doi.org/10.22216/jcc.v3i1.1308 